Article

\title{
Estrogen and Thyroid Hormone Receptor Activation by Medicinal Plants from Bahia, Brazil
}

\author{
Luã Tainã Costa Reis ${ }^{1}$ (1), Magnus Régios Dias da Silva ${ }^{2}$, Silvia Lima Costa ${ }^{3}$, \\ Eudes da Silva Velozo ${ }^{4}$, Ronan Batista ${ }^{5}$ (1) and Suzana Telles da Cunha Lima ${ }^{1, *}$ \\ 1 Laboratory of Bioprospection and Biotechnology (LaBBiotec), Institute of Biology, Federal University of \\ Bahia (UFBA), Barão de Jeremoabo Street, 147-Ondina, Salvador, BA 40170-115, Brazil; \\ lua.taina@hotmail.com \\ 2 Laboratory of Molecular and Translational Endocrinology, Department of Medicine, Federal University of \\ São Paulo (UNIFESP), R. Sena Madureira, 1500-Vila Clementino, São Paulo, SP 04021-001, Brazil; \\ silvamagnus@gmail.com \\ 3 Laboratory of Neurochemistry and Cell Biology, Department of Biofunction, Institute of Health Sciences, \\ Federal University of Bahia (UFBA), Reitor Miguel Calmon Avenue, 1272-Canela, Salvador, BA 40231-300, \\ Brazil; costasl@ufba.br \\ 4 Laboratory of Research in Materia Medica, Department of Medicament, Faculty of Pharmacy, \\ Federal University of Bahia (UFBA), Barão de Jeremoabo Street, 147-Ondina, Salvador, BA 40170-115, Brazil; \\ euvelozo@ufba.br \\ 5 Department of Organic Chemistry, Institute of Chemistry, Federal University of Bahia (UFBA), \\ Barão de Jeremoabo Street, 147-Ondina, Salvador, BA 40170-115, Brazil; ronbatis@ufba.br \\ * Correspondence: stcunhalima@ufba.br; Tel.: +55-71-987-938-847
}

Received: 23 December 2017; Accepted: 11 January 2018; Published: 15 January 2018

\begin{abstract}
Background: A number of medicinal plants are traditionally used for metabolic disorders in Bahia state, Brazil. The aim of this study was to evaluate the estrogen receptor (ER) and thyroid receptor (TR) activation of crude extracts prepared from 20 plants. Methods: Species were extracted and assayed for receptor activation through both ER and TR gene-reporter assays, using $17 \beta$-estradiol and triiodothyronine (T3), respectively, as the positive controls. Results: Cajanus cajan (Fabaceae), Abarema cochliacarpus (Fabaceae), and Borreria verticillata (Rubiaceae) were able to activate ER as much as the positive control (17 $\beta$-estradiol). These three plant species were also assayed for TR activation. At the concentration of $50 \mu \mathrm{g} / \mathrm{mL}, C$. cajans exerted the highest positive modulation on TR, causing an activation of $59.9 \%$, while B. verticillata and A. cochliacarpus caused $30.8 \%$ and $23.3 \%$, respectively. Conclusions: Our results contribute towards the validation of the traditional use of C. cajans, B. verticillata, and A. cochliacarpus in the treatment of metabolic disorders related to ER and TR functions. The gene-reporter assay was proven effective in screening crude plant extracts for ER/TR activation, endorsing this methodology as an important tool for future bioprospection studies focused on identifying novel starting molecules for the development of estrogen and thyroid agonists.
\end{abstract}

Keywords: nuclear receptor; estrogen hormone receptor; thyroid hormone receptor; metabolic disorders; Brazilian medicinal plants

\section{Introduction}

Nuclear receptors (NRs) are proteins that form a superfamily of eukaryotic transcription factors; their function is dependent on ligand binding, and they are evolutionarily correlated. The relevance of this group of proteins in metabolic disease is shown by numerous synthetic ligands used in the clinic or under exploratory development for the treatment of diabetes mellitus, dyslipidemia, hypercholesterolemia, or other metabolic abnormalities [1]. These transcriptional activators play 
an important role in cell signaling through signal transduction in biological responses and on regulatory activity of gene expression over specific targets. This function is performed through the recruitment of co-regulator complexes in genome-specific sites in response to the binding of small molecules such as steroids and thyroid hormones, retinoic acid, vitamin D, fatty acids, and eicosanoids [2,3]. Nuclear receptors display a common molecular structure consisting of an amino terminal region (NTD), with variable amino acid sequence and length, a DNA-binding domain (DBD) which is quite conserved, a ligand-binding domain (LBD) which binds the ligand molecules specific to each receptor, and a region that connects the DBD with LBD, called Hinge $(\mathrm{H})[2,4]$.

The receptor of estrogen hormone (ER) through $17 \beta$-estradiol participates in several physiological functions, including the development of secondary sexual characteristics, actions in the vascular system, energetic and bone metabolism, as well as implications in pathologies such as breast cancer that are also strongly associated with control by the receptor $[5,6]$. On the other hand, thyroid hormone receptors (TRs) are disseminated by various organs in the human body. They are mainly expressed in the liver, pituitary, inner ear, retina, and several brain areas, playing an important role in growth, development and differentiation, as well as in the regulation of key metabolic processes, such as lipogenesis, lipolysis, and thermogenesis [7-9]. Mutations in these receptors with hotspots in the LBD binding domain are related to thyroid hormone resistance syndrome [10].

Due to the requirement of interactionwith hormones or other ligands to exercise their function, NRs are good therapeutic targets, since synthetic agonist and antagonist molecules can be drawn, controlling the transcriptional function of the receptor. In addition, a promising approach is the search for molecules from medicinal plants that can act by modulating the activity of these receptors.

Natural products have great importance in the prevention and treatment of diseases. They have been associated with humankind since ancient times, being the only alternatives for the treatment of diseases before the 20th century [11,12]. Researchers stated that even though 250-500 thousand species of flowering plants were known at that year (2007), only 5\% were registered in the literature for medicinal uses, which highlights the amount of pharmacological information still not explored, even today [13].

Metabolic and immune systems are essential for life, and this is believed to be the reason why they have been evolutionarily conserved throughout species. Consequently, immune response and metabolic regulation are highly integrated and constitute a central homeostatic mechanism, whose functions depends on each other. Within this scenario, a disruption of normal metabolic processes may occur. Thus, metabolic disorders can be defined as a group of pathophysiological conditions in which there is deficiency in the production, metabolism, storage, or transport of biochemically important compounds, leading to a cluster of chronic imbalance disorders-particularly obesity, type 2 diabetes, and cardiovascular disease. These diseases currently constitute a large burden of morbidity and mortality, impacting global human health and welfare $[14,15]$. According to the National Institutes of Health (NIH) [16], metabolic disorders are closely related to a few risk factors, including obesity, a high triglyceride and a low high-density lipoprotein (HDL) cholesterol level, high blood pressure, and high fasting blood sugar (leading to diabetes).

In this study, twenty medicinal plants indicated for metabolic diseases were selected from a couple of ethnobotanical surveys conducted in Bahia state, Brazil. All selected plant species were assessed for estrogen hormone receptor (ER) activation through the ER gene-reporter assay, and only those which confirmed significant modulatory activity over ER were also assessed for thyroid hormone receptor $(\mathrm{TR} \beta)$ activation.

\section{Materials and Methods}

\subsection{Selection of Plant Species}

Starting from surveys conducted in both Pataxó indigenous and Salvador communities, Bahia state, Brazil $[17,18]$, this study selected twenty plants indicated for the treatment of metabolic disorders 
(Table 1). These plant species were collected, and the corresponding voucher specimens were deposited at the Alexandre Leal Costa Herbarium (ALCB) of the Federal University of Bahia (UFBA), Salvador, Bahia, Brazil, under the code listed in Table 1.

\subsection{Obtaining Extracts}

Initially, the used part of each plant species (Table 1) was separately dried in an oven at $50{ }^{\circ} \mathrm{C}$, and then powdered in a mill to a fine grade. This plant material $(1 \mathrm{~g})$ was exposed to ethanol $96 \%$ thorough soaking $(1: 9 \mathrm{w} / \mathrm{v})$ for $48 \mathrm{~h}$, yielding an ethanol solution which followed centrifugation and separation from pellets. All ethanol extracts were assessed for the estrogen receptor (ER) activation through the corresponding reporter gene-assay, and only the most active ones were subjected to the thyroid receptor (TR) activation assay.

In order to prepare extracts for the TR assay, the selected plant material (powder) was first defatted by maceration with hexane and then soaked with methanol at room temperature to afford-after concentration under reduced pressure - the corresponding methanol extract, which was stored at $4{ }^{\circ} \mathrm{C}$ until use.

\subsection{Transformation and Purification}

$\mathrm{DH} 5 \alpha$ Escherichia coli-competent cell was transformed separately with two CMV plasmids containing the PGK1 (luciferase) gene and the other, the TR $\beta$ gene (kindly given by Paul Webb, Diabetes Center-University of California San Francisco), in the concentrations of $1 \mu \mathrm{g} / \mu \mathrm{L}$ each. Bacteria and plasmids were incubated for $30 \mathrm{~min}$ on ice, subject to thermal shock by $1 \mathrm{~min}$ at $42{ }^{\circ} \mathrm{C}$, followed by 2 min on ice. Subsequently $250 \mu \mathrm{L}$ of S.O.C medium (Invitrogen) were added and the mixture incubated for $1.5 \mathrm{~h}$ at $37^{\circ} \mathrm{C}$ under agitation of $180 \mathrm{rpms}$. After centrifugation at $2000 \mathrm{rpm}$, the bacterial pellet was re-suspended in $50 \mu \mathrm{L}$ of S.O.C and plated in Petri dishes with LB solid medium containing ampicillin $(100 \mu \mathrm{g} / \mathrm{mL})$ for $12 \mathrm{~h}$. A colony was collected and grown in $500 \mathrm{~mL} \mathrm{LB}$, containing ampicillin $(100 \mu \mathrm{g} / \mathrm{mL})$ for $12 \mathrm{~h}$. The liquid culture was centrifuged at $2000 \mathrm{rpm}$, and the plasmids were purified according to the Qiagen Protocol of Maxi prep Plasmid Purification Kit.

\subsection{Human HEK Cells Cultivation}

For human HEK cell cultivation, 292 HEK cells were seeded and grown in Dulbecco's Modified Eagle Medium (DMEM) (GIBCO) pH 7.2 supplemented with $1.7 \mathrm{~g}$ of sodium bicarbonate, $5 \mathrm{~mL}$ of penicillin/streptomycin $5000 \mathrm{U} / \mathrm{mL}$ (GIBCO), and $10 \mathrm{mM}$ HEPES containing 10\% fetal bovine serum (FBS) and filtered in Millipore filter $0.2 \mu \mathrm{m}$.

\subsection{ER Reporter GeneAssay}

This procedure was adapted from previously reported methodologies $[19,20]$. Briefly, ethanol extracts were dissolved in ethanol to produce stock solutions at $100 \mathrm{mg} / \mathrm{mL}$. Each of the plasmids $(1 \mu \mathrm{g})$ was used to transfect Hela cells by electroporation. Plasmids used were CMVs containing either Full Length ER, luciferase gene (PGK1) or $\beta$-Gal (transfection control). After incubation for $24 \mathrm{~h}$, a given ethanolic extract $(10 \mu \mathrm{g})$ was used per well $(2 \mathrm{~mL})$ in a 6 well plate. 17 $\beta$-estradiol (Sigma-Aldrich, Darmstadt, Germany, $1 \mu \mathrm{M}$ ) was used as the positive control. After overnight incubation, the luminescence reading (in RLU) was made in an illuminometer and the control $(\beta-\mathrm{Gal})$, in a spectrophotometer, at $460 \mathrm{~nm}$. The reading data were plotted in Graph Pad Prism, and the activation coefficients (luciferase) were calculated by comparison to the positive control. Each luminometer reading reflects activation of the receptor by each ethanol extract when compared to the synthetic estrogen. 


\subsection{TR Reporter Gene Assay}

Methanol extracts were dissolved in DMSO to prepare stock solutions at $40 \mathrm{mg} / \mathrm{mL}$. Final concentrations tested in cells were 50 and $100 \mu \mathrm{g} / \mathrm{mL}$ in DMEM-which were demonstrated to be the maximum added to cells $(100 \mu \mathrm{g} / \mathrm{mL})$ without causing cell death superior to the positive control with triiodothyronine (T3) — for all plants.

HEK cells were transfected using calcium phosphate method [21]. Cells were grown in $10 \mathrm{~mm}$ plates until confluence of $60 \%$. The medium was aspirated and cells released from the bottom with $1 \mathrm{~mL}$ of trypsin for $3 \mathrm{~min}$. After homogenization, $2 \mathrm{~mL}$ of DMEM medium was added and the mixture centrifuged for $5 \mathrm{~min}$ at $1000 \mathrm{rpm}$. The pellet was resuspended in $1 \mathrm{~mL}$ of medium, distributed in the twelve wells, each containing $1 \mathrm{~mL}$ of medium. Cells were grown overnight at $37^{\circ} \mathrm{C}$. One hour prior to transfection, the medium was replaced by DMEM without FBS. Twenty-four micrograms of plasmidial DNA (12 $\mu \mathrm{g}$ of PGK1 and $12 \mu \mathrm{g}$ TR $\beta$ ) were added to the $76.25 \mu \mathrm{L}$ of $2 \mathrm{M} \mathrm{CaCl}_{2}$ solution, and the final volume of $625 \mu \mathrm{L}$ was completed with ultra-pure water. This solution was then added to $625 \mu \mathrm{L}$ of HEPES $0.05 \mathrm{M}\left(1.6 \mathrm{~g} \mathrm{NaCl}, 0.021 \mathrm{~g} \mathrm{Na}_{2} \mathrm{HPO}_{4}\right.$, and $1.3 \mathrm{~g}$ HEPES in $100 \mathrm{~mL}$ water, $\left.\mathrm{pH} 7.0\right)$ and left for $15 \mathrm{~min}$ at room temperature. One hundred microliters $(100 \mu \mathrm{L})$ of the final solution were added to each well in the 12 -well plate. The cells then stayed at $37^{\circ} \mathrm{C}$ for two hours. Subsequently, the transfection medium was removed, cells were washed twice with phosphate-buffered saline (PBS), and DMEM medium containing 10\% FBS was added. Reporter-gene assay was used for evaluation of gene expression regulated by plant extracts. The positive control was triiodothyronine (T3) in a final concentration of $1 \mathrm{nM}$ (Sigma-Aldrich). Readings of activation used a Dual-Glo ${ }^{\circledR}$ luciferase assay system (E2920, PROMEGA, Madison, WI, USA) according to instructions of the company, and results were obtained according to readings in a luminometer (in RLU).

\subsection{Statistical Analysis}

Statistical analysis was performed in Graphpad Prism 5 (Garph Pad Software, La Jolla, CA, USA), and differences among the data obtained were performed with Wilcoxon test with significance values of $p<0.05$. Evaluations were non-parametric, as paired sample tests, and three analytical replicates per sample. The graphical expression was performed using mean, standard error, and data values converted into percentage in relation to positive control.

\section{Results and Discussion}

Ethanol extracts obtained from all 20 plants listed in Table 1 were assessed for ER activation, and the results are shown in Figure 1. As can be seen, only the crude extracts E5 (Cajanus cajan, Fabaceae), E18 (Abarema cochliacarpus, Fabaceae), and E20 (Borreria verticillata, Rubiaceae) were able to produce an ER activation comparable to that observed for the positive control $17 \beta$-estradiol (Figure 1), and for this reason they were classified as active extracts. The ER activation of the remaining ethanol extracts was very similar to or lower than that observed for the negative control, and thus these crude extracts were considered to be inactive.

Bearing in mind that estrogen and thyroid receptors crosstalk to each other [22], it was assumed that ER activation might be used as predictor for TR activation. Thus, the three plant species active on ER were selected for the following TR activation assay. Methanol extracts were obtained and assayed for TR activation, and the corresponding results are depicted in Figure 2. Interestingly, all three extracts showed wide variation of TR $\beta$ activation, but with increased response at $50 \mu \mathrm{g} / \mathrm{mL}$ compared to $100 \mu \mathrm{g} / \mathrm{mL}$. These findings reveal that the activation of such receptors is strongly associated with extract concentration. At the concentration of $50 \mu \mathrm{g} / \mathrm{mL}$, C. cajans presented an activation of $59.9 \%$, while B. verticillata and A. cochliacarpus did $30.8 \%$ and $23.3 \%$, respectively. At $100 \mu \mathrm{g} / \mathrm{mL}$, the corresponding values were respectively $17.4 \%, 14.9 \%$, and $7.1 \%$ (Figure 2 ). In agreement with these results, the crude ethanol extract of $C$. cajans (L.) Millsp. was demonstrated to exert higher positive modulation on TR when compared to B. verticillata and A. cochliacarpos. 
Table 1. Plants used in Bahia, Brazil, referred to as having therapeutic properties against metabolic disorders.

\begin{tabular}{|c|c|c|c|c|c|c|}
\hline Code & Species & Family & Voucher $n^{\circ}($ ALCB $)$ & Vernacular Name & Indication & Part Used \\
\hline E1 & Cissus verticilata $\mathrm{L}$. & Vitaceae & 102,060 & Insulina & hypertension, diabetes & leaf \\
\hline E2 & Syzygium cumini (L.) Skeels & Myrtaceae & 76,156 & Jamelão & obesity, diabetes & leaf \\
\hline E3 & Bidens pilosa $\mathrm{L}$. & Asteraceae & 23,464 & Picão, Carrapixo & diabetes, menstrual disorders & whole plant \\
\hline E4 & Petiveria alliaceae $\mathrm{L}$. & Phytolaccaceae & 123,358 & Guine & diabetes & leaf \\
\hline E5 & Cajanus cajan (L.) Millsp & Fabaceae & 76,098 & Feijão Guandu & diabetes & leaf, flower \\
\hline E6 & Rosmarinus officinalis L. & Lamiaceae & 76,128 & Alecrim do Reino & metabolic syndrome, human fertility & leaf \\
\hline E7 & Croton heliotropiifolius Kunth & Euphorbiaceae & 108,456 & Caçutinga & diabetes, Alzheimer, Parkinson & flowers and leaf \\
\hline E8 & Sambucus australis Cham. & Caprifoliaceae & 76,145 & Sabugueiro & abdominal adiposity; obesity & stem, flowers \\
\hline E9 & Senna angulata (Vogel) & Fabaceae & $12,375 *$ & Sene & obesity & bark, seed \\
\hline E10 & Psidium guajava Raddi & Myrtaceae & 78,144 & Goiabeira & diabetes & leaf, buds \\
\hline E11 & Maytenus ilicifolia (Schrad.) & Celastraceae & 92,411 & Espinheira-Santa & obesity & leaf \\
\hline E12 & Baccharis trimera (Less.) DC & Asteraceae & 76,132 & Carqueja & obesity, diabetes & aerial parts \\
\hline E13 & Cinchona officinalis L. & Rubiaceae & 12,010 & Quina-Quina & cholesterol disorders, obesity & leaf \\
\hline E14 & Cinnamomum zeylanicum Blume & Lauraceae & 76,099 & Canela & cardiopathies, diabetes & bark \\
\hline E15 & Alpinia nutans Roscoe & Zingiberaceae & 76,123 & Levante & metabolic disorders & leaf, rhizome \\
\hline E16 & Peperomia pellucida (DC.) H.B.K. & Piperaceae & 78,145 & Alfavaca-de-cobra & cholesterol disorders, obesity, diabetes & leaf, seed \\
\hline E17 & Plantago major (L.) & Plantaginaceae & 95,608 & Trancagem & diabetes & leaf and seeds \\
\hline E18 & $\begin{array}{c}\text { Abarema cochliacarpus (Gomes) } \\
\text { Barneby \& J.W. Grimes }\end{array}$ & Fabaceae & 76,158 & Barbatimão & obesity, diabetes & whole plant \\
\hline E19 & Byrsonima sericea DC. & Malpighiaceae & 78,150 & Murici & obesity & leaf \\
\hline E20 & Borreria verticillata (L.) G. Mey. & Rubiaceae & 76,113 & Tiririca de Babado & obesity, diabetes, fever and flu & leaf \\
\hline
\end{tabular}

${ }^{*}$ Housed at the Herbarium of the Federal University of Pará (UFP), Brazil. ALCB: Alexandre Leal Costa Herbarium. 


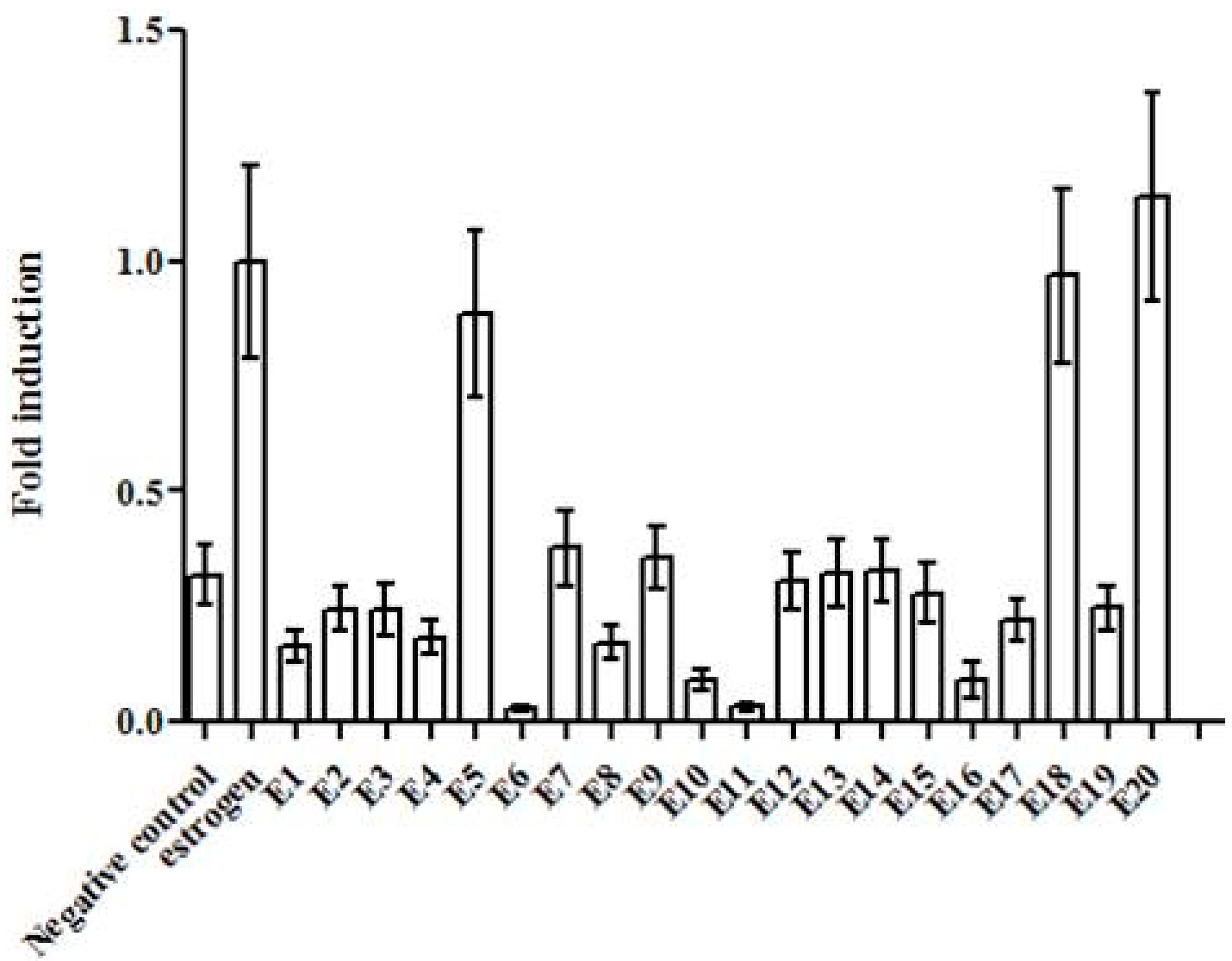

Figure 1. Estrogen receptor (ER) activation by selected ethanol plant extracts. E1: Cissus verticilata; E2: Syzygium cumini; E3: Bidens pilosa; E4: Petiveria alliaceae; E5: Cajanus cajan; E6: Rosmarinus officinalis; E7: Croton heliotropiifolius; E8: Sambucus australis; E9: Senna angulata; E10: Psidium guajava; E11: Maytenus ilicifolia; E12: Baccharis trimera; E13: Cinchona officinalis; E14: Cinnamomum zeylanicum; E15: Alpinia nutans; E16: Peperomia pellucida; E17: Plantago major; E18: Abarema cochliacarpus; E19: Byrsonima sericea; E20: Borreria verticillata. Data are displayed in average fold induction compared to the positive control (100\%) $17 \beta$-Estradiol (estrogen). Bars represent the standard deviation of three repetitions $(n=3)$.

Plant molecules with modulator roles over receptors are important not only due to the great ability to produce biomolecules with different structures, but also for their contribution to the knowledge of compounds produced by flora [23,24]. Many molecules from natural sources have already been described in the literature as modulators of nuclear receptors [25-27]. Genistein, an isoflavone implicated as causative for the estrogenic activity of red clover [28], is one of the known chemical components of $C$. cajan [29] and may explain—at least in part-both ER and TR activation observed for this plant in the present study. B. verticillata contains iridoids as chemical constituents [30,31], which are a recognized class of natural products which actively modulate estrogen receptors [32]. Finally, A. cochliacarpos is a plant species rich in catechins and polyphenols, which are probably the components of this plant which are active on the ER.

Although there is an increasing interest in isolating active compounds, plant extracts have innumerable molecules that may act synergistically in modulating nuclear receptors, as demonstrated by Lin [33]. In addition to that, extracts have the ability to increase the nuclear receptor activity-even when it is saturated with endogenous ligands-through binding outside the hormone pocket, in allosteric response, as seen by Ong and Tan [25] for androgenic hormone receptor. Products of natural origin-whether from plant, animal, or microbial-represent an almost inexhaustible source of molecular structures that can be useful for therapeutic purposes, or as a model to design new chemical molecules. The results achieved in the present work are of utmost relevance within the field of natural 
products and nuclear receptors, since it is the first time a plant extract has been reported to exhibit thyroid hormone receptor modulation.

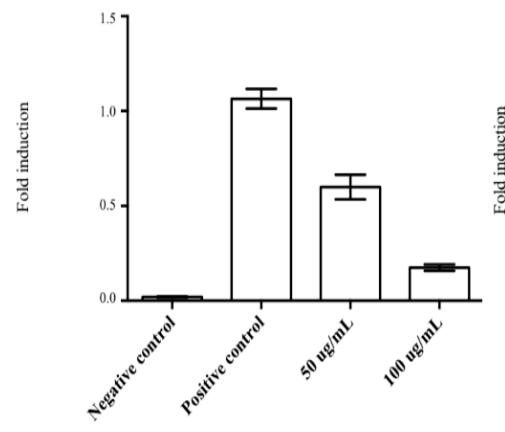

Cajanus cajan (L.) Nillsp

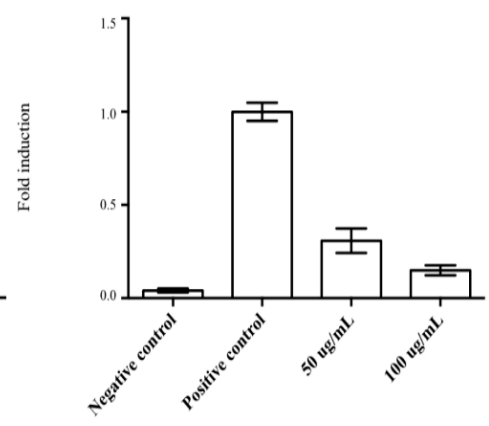

Borreria verticillata (L.) G. Mey

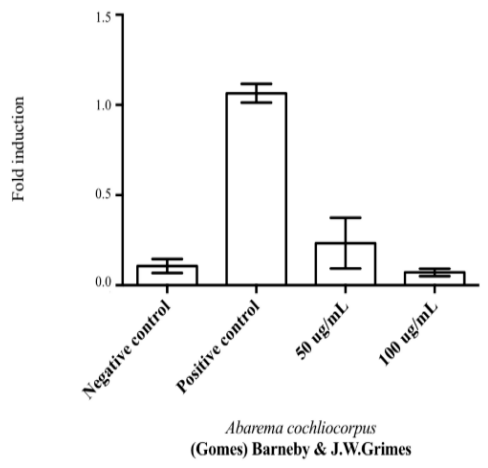

Figure 2. Activation of thyroid receptor $\beta(\mathrm{TR} \beta)$ by selected methanol plant extracts. Data are displayed in average fold induction compared to the positive control (100\%) triiodothyronine (T3). Bars represent the standard deviation of three repetitions $(n=3)$.

Our findings contribute towards the validation of the traditional use of Cajanus cajans, Borreria verticillata, and Abarema cochliacarpus in the treatment of metabolic disorders-mainly those related to ER and TR functions. Moreover, the gene-reporter assays for ER and TR described in this study were proved effective to screen crude plant extracts for ER/TR activation, and reveal that this methodology may display an important role in future bioprospection studies focused on identifying novel chemical entities as starting molecules for the development of estrogen and thyroid agonists.

Author Contributions: S.T.d.C.L. and R.B. conceived the study. E.d.S.V. obtained all extracts, and L.T.C.R. executed assays under supervision of S.L.C. and M.R.D.d.S. S.T.d.C.L. and R.B. drafted the manuscript.

Conflicts of Interest: The authors declare no conflict of interest.

Funding: This work was supported by Fundação de Amparo à Pesquisa do Estado da Bahia (FAPESB), as a Graduate Fellowship.

\section{References}

1. Sonoda, J.; Pei, L.; Evans, R.M. Nuclear receptors: Decoding metabolic disease. FEBS Lett. 2008, 582, 2-9. [CrossRef] [PubMed]

2. Helsen, C.; Kerkhofs, S.; Clinckemalie, L.; Spans, L.; Laurent, M.; Boonen, S.; Vanderschueren, D.; Claessens, F. Structural basis for nuclear hormone receptor DNA binding. Mol. Cell. Endocrinol. 2012, 348, 411-417. [CrossRef] [PubMed]

3. Edwards, D.P. The Role of Coactivators and Corepressors in the Biology and Mechanism of Action of Steroid Hormone Receptors. J. Mammary Gland Biol. Neoplasia 2000, 5, 307-324. [CrossRef] [PubMed]

4. Clinckemalie, L.; Vanderschueren, D.; Boonen, S.; Claessens, F. The hinge region in androgen receptor control. Mol. Cell. Endocrinol. 2012, 358, 1-8. [CrossRef] [PubMed]

5. Arnal, J.-F.; Valéra, M.-C.; Payrastre, B.; Lenfant, F.; Gourdy, P. Structure-function relationship of estrogen receptors in cardiovascular pathophysiological models. Thromb. Res. 2012, 130, S7-S11. [CrossRef] [PubMed]

6. Jia, M.; Dahlman-Wright, K.; Gustafsson, J.-A. Estrogen receptor alpha and beta in health and disease. Best Pract. Res. Clin. Endocrinol. Metab. 2015, 29, 557-568. [CrossRef] [PubMed]

7. Goglia, F.; Moreno, M.; Lanni, A. Action of thyroid hormones at the cellular level: The mitochondrial target. FEBS Lett. 1999, 452, 115-120. [CrossRef]

8. Pascual, A.; Aranda, A. Biochimica et Biophysica Acta Thyroid hormone receptors, cell growth and differentiation. BBA Gen. Subj. 2013, 1830, 3908-3916. [CrossRef] [PubMed]

9. Flamant, F.; Baxter, J.D.; Forrest, D.; Refetoff, S.; Samuels, H.; Scanlan, T.S.; Vennstrom, B.; Samarut, J. International Union of Pharmacology. LIX. The Pharmacology and Classification of the Nuclear Receptor Superfamily: Thyroid Hormone Receptors. Pharmacol. Rev. 2006, 58, 705-711. [CrossRef] [PubMed] 
10. Işık, E.; Beck-Peccoz, P.; Campi, I.; Özön, A.; Alikaşifoğlu, A.; Gönç, N.; Kandemir, N. Thyroid hormone resistance: A novel mutation in thyroid hormone receptor beta (THRB) gene-Case report. Turk. J. Pediatr. 2013, 55, 322-327. [PubMed]

11. Lahlou, M. The Success of Natural Products in Drug Discovery. Pharmacol. Pharm. 2013, 4, 17-31. [CrossRef]

12. Rates, S.M.K. Plants as source of drugs. Toxicon 2001, 39, 603-613. [CrossRef]

13. McChesney, J.D.; Venkataraman, S.K.; Henri, J.T. Plant natural products: Back to the future or into extinction? Phytochemistry 2007, 68, 2015-2022. [CrossRef] [PubMed]

14. Hotamisligil, G.S. Inflammation and metabolic disorders. Nature 2006, 444, 860-867. [CrossRef] [PubMed]

15. Rani, V.; Deep, G.; Singh, R.K.; Palle, K.; Yadav, U.C.S. Oxidative stress and metabolic disorders: Pathogenesis and therapeutic strategies. Life Sci. 2016, 148, 183-193. [CrossRef] [PubMed]

16. National Institutes of Health (NIH). Available online: https:/ / www.nhlbi.nih.gov (accessed on 10 June 2017).

17. Lima, S.T.C.; Rodrigues, E.D.; Merrigan, T.L.; Melo, T.; Guedes, M.L.S.; Nascimento, A.F.; Toralles, M.B. The use of medicinal plants by an indigenous Pataxó community in NE Brazil. Rev. Bras. Plantas Med. 2012, 14, 84-91.

18. Lima, S.T.C.; Rodrigues, E.D.; Melo, T.; Nascimento, A.F.; Guedes, M.L.S.; Cruz, T.; Alves, C.; Meyer, R.; Toralles, M.B. Levantamento da flora medicinal usada no tratamento de doenças metabólicas em. Rev. Bras. Plantas Med. 2008, 10, 83-89.

19. Legler, J.; van den Brink, C.; Brouwer, A.; Murk, A.J.; van der Saag, P.T.; Vethaak, A.D.; van der Burg, B. Development of a Stably Transfected Estrogen Receptor-Mediated Luciferase Reporter Gene Assay in the Human T47D Breast Cancer Cell Line. Toxicol. Sci. 1999, 48, 55-66. [CrossRef] [PubMed]

20. Du, J.; Wei, Y.; Peng, C.; Ran, X.; Zhang, H.; Jiang, Y.; Rahman, K.; Qin, L. Establishment of a luciferase assay-based screening system for detecting estrogen receptor agonists in plant extracts. Bone 2011, 49, 572-579. [CrossRef] [PubMed]

21. Jordan, M.; Schallhorn, A.; Wurm, F.M. Transfecting mammalian cells: Optimization of critical parameters affecting calcium-phosphate precipitate formation. Nucleic Acids Res. 1996, 24, 596-601. [CrossRef] [PubMed]

22. Vasudevan, N.; Koibuchi, N.; Chin, W.W.; Pfaff, D.W. Differential crosstalk between estrogen receptor (ER)a and $\mathrm{ERb}$ and the thyroid hormone receptor isoforms results in flexible regulation of the consensus ERE. Mol. Brain Res. 2001, 95, 9-17. [CrossRef]

23. Gullo, V.P.; McAlpine, J.; Lam, K.S.; Baker, D.; Petersen, F. Drug discovery from natural products. J. Ind. Microbiol. Biotechnol. 2006, 33, 523-531. [CrossRef] [PubMed]

24. Agra, M.D.F.; de Freitas, P.F.; Barbosa-Filho, J.M. Synopsis of the plants known as medicinal and poisonous in Northeast of Brazil. Brazilian J. Pharmacogn. 2007, 17, 114-140. [CrossRef]

25. Ong, V.Y.C.; Tan, B.K.H. Novel phytoandrogens and lipidic augmenters from Eucommia ulmoides. BMC Complement. Altern. Med. 2007, 7, 1-11. [CrossRef] [PubMed]

26. Burris, T.P.; Montrose, C.; Houck, K.A.; Osborne, H.E.; Bocchinfuso, W.P.; Yaden, B.C.; Cheng, C.C.; Zink, R.W.; Barr, R.J.; Hepler, C.D.; et al. The Hypolipidemic Natural Product Guggulsterone Is a Promiscuous Steroid Receptor Ligand. Mol. Pharmacol. 2005, 67, 948-954. [CrossRef] [PubMed]

27. He, Y.-Q.; Ma, G.-Y.; Peng, J.; Ma, Z.-Y.; Hamann, M.T. Biochimica et Biophysica Acta Liver X receptor and peroxisome proliferator-activated receptor agonist from Cornus alternifolia. Biochim. Biophys. Acta 2012, 1820, 1021-1026. [CrossRef] [PubMed]

28. Liu, J.; Burdette, J.E.; Xu, H.; Gu, C.; van Breemen, R.B.; Bhat, K.P.L.; Booth, N.; Constantinou, A.I.; Pezzuto, J.M.; Fong, H.H.S.; et al. Evaluation of Estrogenic Activity of Plant Extracts for the Potential Treatment of Menopausal Symptoms. J. Agric. Food Chem. 2001, 49, 2472-2479. [CrossRef] [PubMed]

29. Duker-Eshun, G.; Jaroszewski, J.W.; Asomaning, W.A.; Oppong-Boachie, F.; Christensen, S.B. Antiplasmodial constituents of Cajanus cajan. Phyther. Res. 2004, 18, 128-130. [CrossRef] [PubMed]

30. Vieira, I.J.C.; Mathias, L.; Braz-Filho, R.; Schripsema, J. Iridoids from Borreria verticillata. Org. Lett. 1999, 1, 1169-1171. [CrossRef]

31. Moreira, F.; Oliveira, R.R.; Mathias, L.; Braz-filho, R.; Vieira, I.J.C.V. New Chemical Constituents from Borreria verticillata (Rubiaceae). Helv. Chim. Acta 2010, 93, 1751-1757. [CrossRef] 
32. Wang, H.; Li, M.-C.; Yang, J.; Yang, D.; Su, Y.-F.; Fan, G.-W.; Zhu, Y.; Gao, X.-M.; Paoletti, R. Estrogenic properties of six compounds derived from Eucommia ulmoides Oliv. and their differing biological activity through estrogen receptors a and b. Food Chem. 2011, 129, 408-416. [CrossRef]

33. Lin, F.-M.; Chen, L.-R.; Lin, E.-H.; Ke, F.-C.; Chen, H.-Y.; Tsai, M.-J.; Hsiao, P.-W. Compounds from Wedelia chinensis synergistically suppress androgen activity and growth in prostate cancer cells. Carcinogenesis 2007, 28, 2521-2529. [CrossRef] [PubMed]

2018 by the authors. Licensee MDPI, Basel, Switzerland. This article is an open access article distributed under the terms and conditions of the Creative Commons Attribution (CC BY) license (http://creativecommons.org/licenses/by/4.0/). 